Western North American Naturalist 70(2), (C) 2010, pp. 258-260

\title{
CLIMBING AS AN ESCAPE BEHAVIOR IN THE AMERICAN HOG-NOSED SKUNK, CONEPATUS LEUCONOTUS
}

\author{
Wesley A. Brashear ${ }^{1}$, Robert C. Dowler ${ }^{1,3}$, and Gerardo Ceballos ${ }^{2}$
}

\begin{abstract}
Climbing behavior is poorly documented in skunk species, with the exception of the genus Spilogale. Herein we describe 2 cases of climbing behavior in the American hog-nosed skunk (Conepatus leuconotus): one in Colima, Mexico, and another in west central Texas, USA. In both cases, a male climbed over $5 \mathrm{~m}$ into oak trees when pursued by humans. Climbing as an escape behavior in hog-nosed skunks has not previously been reported.
\end{abstract}

Key words: hog-nosed skunk, Conepatus, climbing, Texas, México.

In the family Mephitidae, the ability to climb is well documented only in the genus Spilogale. The eastern spotted skunk (Spilogale putorius) and the western spotted skunk (Spilogale gracilis) are both well known for their arboreal agility. Spilogale putorius is reported to hunt in trees, reducing competition with sympatric terrestrial carnivores, and to use cavities in trunks or branches as den sites (Kinlaw 1995). In S. gracilis, tree cavities and hollow logs comprised $6 \%$ of the den sites at a study site in west central Texas (Doty and Dowler 2006). Though in a sister taxon to Spilogale (Dragoo and Honeycutt 1997), members of the genus Mephitis are not considered climbers because of their forelimb morphology (Iwaniuk et al. 1999); however, they have been reported to climb on rare occasions (Haas 2003, Dragoo 2009).

Members of the genus Conepatus have been reported to have strong forelimbs and the ability to climb (Dragoo and Honeycutt 1999, De la Rosa and Nocke 2000, Dragoo and Sheffield 2009); but this behavior, to our knowledge, has never been reported for individuals other than captives. Herein we report 2 observations of climbing in the American hog-nosed skunk, Conepatus leuconotus, as a response to pursuit by humans.

In March 1995, one of us (GC) found a male hog-nosed skunk in the El Jabalí private reserve in Colima, México (190 $28^{\prime} 27^{\prime \prime} \mathrm{N}, 103^{\circ} 40^{\prime} 28^{\prime \prime} \mathrm{W}$, $1700 \mathrm{~m})$. El Jabalí is covered by a mixture of cloud and oak forests with disturbed habitats.
The skunk was walking in a pasture with sparse tree and shrub cover. GC pursued the skunk for more than $80 \mathrm{~m}$ and attempted to capture him by hand. The skunk evaded capture by running until he reached an oak tree and readily climbed up to $5 \mathrm{~m}$. The skunk was captured in the tree, positively identified as male, and then released about $20 \mathrm{~m}$ from the tree. The animal ran back and climbed the tree again where he stayed until we left one hour later. A photograph of this animal appears in Mendoza Durán and Ceballos (2005).

On 26 December 2008, one of us (WAB) was driving a spotlight transect near Knickerbocker in Tom Green County, Texas, attempting to locate and capture hog-nosed skunks for a radio-telemetry study. The habitat was a rocky upland area with scattered plateau live oak (Quercus fusiformis) and sparse understory consisting of mixed grasses and prickly pear (Opuntia spp). The weather was mild, with a high temperature of $25{ }^{\circ} \mathrm{C}$ and a low of $16{ }^{\circ} \mathrm{C}$ recorded for the day at the closest weather station (San Angelo Regional Airport, 17 km NE of the study site).

At approximately 22:15, an individual $C$. leuconotus was observed climbing over the base of a live oak. After exiting the vehicle and approaching the skunk, we noticed a second hog-nosed skunk behind the tree. The first skunk was then observed in the oak at a height of $2 \mathrm{~m}$. This skunk was continuing to climb when the second skunk began to run away. We captured the second individual on the ground,

${ }^{1}$ Department of Biology, Angelo State University, San Angelo, TX 76909.

${ }^{2}$ Instituto de Ecología, Universidad Nacional Autonoma de México, México, D.F. 04510, México.

${ }^{3}$ Corresponding author. E-mail: robert.dowler@angelo.edu 


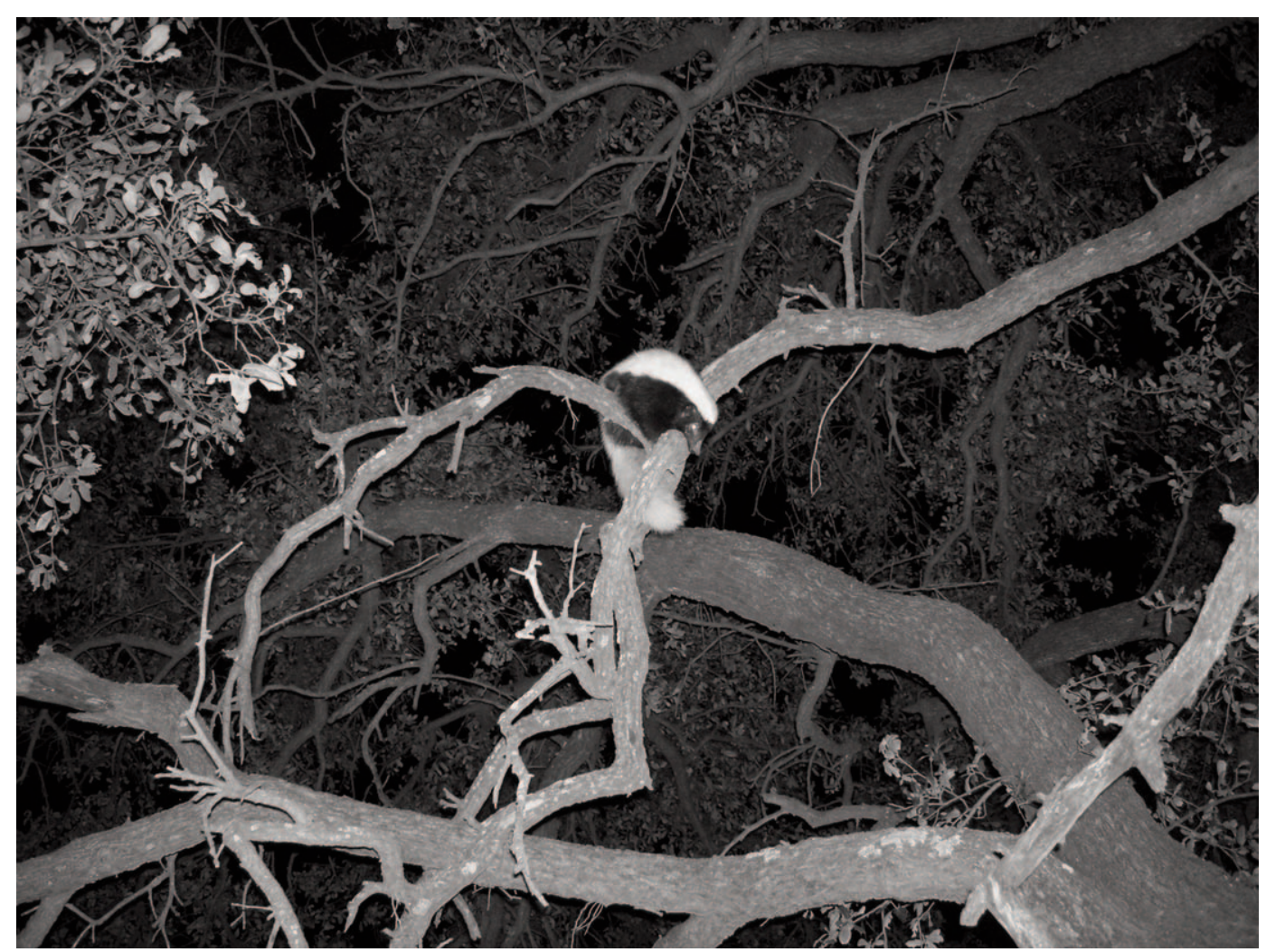

Fig. 1. Photograph of a male American hog-nosed skunk (Conepatus leuconotus) in a plateau live oak (Quercus fusiformis) at a height of $>6 \mathrm{~m}$. Photo was taken in Tom Green County, Texas, USA, on 26 December 2008.

placed it in a cage, and went back to inspect the climbing hog-nosed skunk. Upon our return, the skunk was resting at a height of 6-7 $\mathrm{m}$ (Fig. 1). We decided to radio-collar the captured skunk while waiting to see if the other would return to the ground. The captured skunk was a young nulliparous female $C$. leuconotus with a length of $524 \mathrm{~mm}$ and a mass of $1.2 \mathrm{~kg}$.

During the 30 minutes required to anesthetize and radio-collar the captured female skunk, the skunk in the tree remained at a height of 6-7 m. At about 22:50, we continued the spotlight transect, leaving the skunk in the tree. We captured another C. leuconotus at 23:29 and radio-collared it before returning to the tree at 00:05, finding that the climbing skunk had come down to a height of approximately $2.5 \mathrm{~m}$. We were able to capture the skunk at that time and found it was an individual that had already been eartagged. We anesthetized, examined, radio-collared, and released the animal, which was an adult nonscrotal male with a total length of $595 \mathrm{~mm}$ and a mass of 1.8 $\mathrm{kg}$. On the original date of capture (12 October 2008), the skunk had a mass of $2.0 \mathrm{~kg}$ and was scrotal with testes measuring $25 \times 20 \mathrm{~mm}$.

When we returned to the site the following day, we noticed the immediate area lacked the cover that C. leuconotus seems to favor (e.g., prickly pear patches, rock crevices, or thick brush). In our experience, this species seeks such cover or enters a nearby burrow when pursued. The absence of any of these features at the capture site may explain why the individual chose to climb the tree as an escape behavior. The lack of predation generally experienced by C. leuconotus, coupled with the usual availability of alternative avenues for escape, likely makes climbing as an escape behavior a rare event for this species.

We thank Drew Sykes for permission to use the Knickerbocker Ranch as a study site for 
ecological research on hog-nosed skunks. We also appreciate comments from Jerry W. Dragoo and Adam W. Ferguson on an earlier draft of this manuscript. This research was partially funded by a grant from the James A. "Buddy" Davidson Charitable Foundation to RCD and a Robert G. and Nona K. Carr Student Research Scholarship to WAB. We especially thank Jimmy Brashear for assistance in the field, as well as for the photograph used in this report.

\section{Literature Cited}

De la Rosa, C.L., And C.C. Nocke. 2000. A guide to the carnivores of Central America. University of Texas Press, Austin, TX.

Doty, J.B., AND R.C. Dowler. 2006. Denning ecology in sympatric populations of skunks (Spilogale gracilis and Mephitis mephitis) in west-central Texas. Journal of Mammalogy 87:131-138.

Dragoo, J.W. 2009. Family Mephitidae (skunks). Pages 532-563 in D.E. Wilson and R.A. Mittermeier, editors, Handbook of the mammals of the world. Volume 1, Carnivores. Lynx Edicions, Barcelona, Spain.

Dragoo, J.W., and R.L. HoneycutT. 1997. Systematics of mustelid-like carnivores. Journal of Mammalogy 78: 426-443.
. 1999. Western hog-nosed skunk Conepatus mesoleucus. Pages 191-192 in D.E. Wilson and S. Ruff, editors, The Smithsonian Book of North American Mammals. Smithsonian Institution Press, Washington, DC.

Dragoo, J.W., and S.R. Sheffield. 2009. Conepatus leuconotus (Carnivora: Mephitidae). Mammalian Species 827:1-8.

Hass, C.C. 2003. Ecology of hooded and striped skunks in southeastern Arizona. Final Report to Arizona Game and Fish Department, Phoenix, AZ.

Iwaniuk, A.N., S.M. Pellis, and I.Q. Whishaw. 1999. The relationship between forelimb morphology and behavior in North American carnivores (Carnivora). Canadian Journal of Zoology 77:1064-1074.

KINLAW, A. 1995. Spilogale putorius. Mammalian Species 511:1-7.

Mendoza Durán, A., and G. Ceballos. 2005. Conepatus leuconotus. Pages 386-387 in G. Ceballos and G. Olivia, editors, Los Mamíferos Silvestres de México. Comisión Nacional para el Conocimiento y Usa de Biodiversidad, México D.F.

Received 16 June 2009 Accepted 11 February 2010 